\title{
Effect of Accounting Information Systems, Teamwork, and Internal Control on Financial Reporting Timeliness
}

\author{
Mardi MARDI ${ }^{1}$, Petrolis Nusa PERDANA ${ }^{2}$, Suparno SUPARNO ${ }^{3}$, Imam Aris MUNANDAR ${ }^{4}$
}

Received: September 10, 2020 Revised: November 08, 2020 Accepted: November 16, 2020

\begin{abstract}
This study aims to analyze the factors affecting the timeliness of cooperative financial reporting. The methods of measurement and accountability of financial statements must be timely, as it is critical information for making decision. Factors related to accounting information system problems such as timeliness of financial reporting, accounting information systems, teamwork, and internal control were identified in the study as a model. The method in this research is quantitative by taking survey data. The data were processed using SPSS 25, with a model test and partial test to produce a study to analyze the factors that affect the timeliness of cooperative financial reporting. The samples consisted of 60 cooperatives from the city of Tangerang, in Indonesia. The correspondents have published financial reports for each period of the current year and were a legal entity. Furthermore, primary data were collected by a questionnaire using a Likert scale and analyzed by multiple linear regression. The results showed that the Accounting Information System, Teamwork, and Internal Control had a positive and significant effect on the Timeliness of Financial Report Submission. Therefore, the cooperative that prepares financial reports in a timely manner has applied the principles of accountability and transparency.
\end{abstract}

Keywords: Accounting Information Systems, Teamwork, Internal Control, Timeliness, Financial Reporting

JEL Classification Code: L25, L26, D83, I25, L83

\section{Introduction}

Cooperative as an advance institution, seeks to meet the needs of its members, as well as engage in collaborative activities to manage various businesses that benefit the surrounding community (Asher, 2007; Schenk et al., 2018; Susandya, 2018). The success and progress achieved depend on the workforce of the management and members (as a

${ }^{1}$ First Author and Corresponding Author. Associate Professor, Faculty of Economics, Universitas Negeri Jakarta, Indonesia [Postal Address: Gd. R, Faculty of Economics, Universitas Negeri Jakarta. Campus A, Jl. Rawamangun Muka, East Jakarta, DKI Jakarta, 13220, Indonesia] Email: mardi@unj.ac.id

${ }^{2}$ Lecturer, Faculty of Economics, Universitas Negeri Jakarta, Indonesia. Email: petrolis98@unj.co.id

${ }^{3}$ Lecturer, Faculty of Economics, Universitas Negeri Jakarta, Indonesia. Email: suparno@feunj.ac.id

${ }^{4}$ Faculty of Economics, Universitas Negeri Jakarta, Indonesia. Email: imam.aris.munandar5@gmail.com

(c) Copyright: The Author(s)

This is an Open Access article distributed under the terms of the Creative Commons Attribution Non-Commercial License (https://creativecommons.org/licenses/by-nc/4.0/) which permits unrestricted non-commercial use, distribution, and reproduction in any medium, provided the original work is properly cited. principle of mutual assistance) to increase financial capacity and provide accountability promptly. Also, it is a conscious body of businesses that possess the characteristics of other entities, such as managing and achieving strategic objectives in an organization (Cuevas \& Fischer, 2006; Nashihin \& Harahap, 2014). Ikatan Akuntansi Indonesia (2016) established specific standards for cooperative institutions through Statement of Financial Accounting Standards (PSAK) No. 27 concerning practices performed by business entities (Cleary, 2019; Septariani, 2018; Tanjung, 2017).

Timeliness describes availability of information to users of financial statements before losing the opportunity of influencing economic decisions (Aktaş, 2011; Susandya, 2018; Young, 2017). It affects the relevance of the financial information presented. This information can only be relevant to the user when promptly delivered. Conversely, financial information is said to be irrelevant when there is a delay in reports' submission (Aktaş, 2011; Hwang et al., 2020; Wisna, 2015). When this occurs, the decision taken will not be useful on the assumption that the annual financial statements are not submitted on time by appropriate regulation (Aula \& Budisusetyo, 2018; Kythreotis, 2016; Liyundira et al., 2019; Mathuva, 2019). 
The influence of accounting information systems has been widely studied in various fields of work (Sumaryati et al., 2020), in small and medium enterprises, the accounting information system of small and medium-sized firms in Vietnam (Ha, 2020), even though its impact greatly affects the smoothness of the production reporting process (Arif et al., 2020). Various business fields require strict financial reporting including cluster-based businesses such as Batik in Indonesia (Suparno et al., 2019)

Preparing statements are the responsibility of the cooperative's management during the accounting period. The role of human resources as an important asset drives collaborative industry activities, particularly based on technology (Bhimani, 2014). However, information technology also requires employees to utilize these facilities, such as computing devices that produce and present information more timely, quickly, and accurately (Bhimani, 2014; Jovanović et al., 2017). To support these activities, management needs precise information from financial statements that aim to make strategic decisions (Ghasemi et al., 2011; Jin, 2003; Kane et al., 2016; Rikhardsson \& Yigitbasioglu, 2018).

Similarly, the reliability of information systems enables management to create accountable and transparent reports (Kocsis, 2019; Nicolaou, 2000). A reliable accounting system is largely determined by the ability of managers to identify required information, particularly during compilation. This reliability is very helpful for several entities in organizations with different requirements for the output of the accounting information system (Vysotskaya, 2018; Wisna, 2015). Also, in the process of preparing and submitting reports, the company is greatly influenced by its reliability (Vysotskaya, 2018; Wisna, 2015). Therefore, the use of information systems is based on the principle of giving motivation to the users according to their conviction (Napitupulu, 2020). In entity management, accounting information systems are needed (Septariani, 2018) since they produce accurate and timely reports (Awosejo, Kekwaletswe, Pretorius, \& Zuva, 2013; Huang, 2017; Moffitt \& Vasarhelyi, 2013; Wisna, 2015).

An activity, which creates annual financial statements, consists of several people working as a team following the same strategy (Castner, 2012; Gui et al., 2019; Jin et al., 2019). However, teamwork requires the ability to appropriately and economically utilize resources since the team's superiority in producing financial reports differs from those produced by individual methods. (Bagnoli \& Watts, 2000). Therefore, mutual respect is needed according to the position of members, and this condition needs to be created to facilitate teamwork (Costa et al., 2014; Liaw et al., 2019; Solansky et al., 2017). An entity is made up of individuals that are required to work towards their intended goals (Cha, 2015). Teamwork is needed in the preparation and submission of financial statements since it illustrates the success of the management's performance in providing information (Castner, 2012; Liaw et al., 2019; Rapisarda, 2002; Solansky et al., 2017).

In contrast, maintaining and monitoring the accounting activities requires internal control to produce financial statements that can be used to determine the company's strategy (Ayamga \& Bagina, 2019; Donnell, 2019; Lu et al., 2019). In addition, internal control aims to safeguard the property from a variety of fraud and theft attempts and use of assets in the wrong place (Donnell, 2019). Its activities in the cooperative business provide reasonable guarantees and make timely financial reporting (Almuzaiqer, 2018; Johnston $\&$ Zhang, 2018), encourage the efficiency and effectiveness of entity's operation and promote adherence to management policies (Al-Sharairi et al., 2018; Lu et al., 2019; Noble, 2019). Poor internal control results in inaccurate and late reporting. Conversely, effective control produces financial reports that are timely and provides opportunities for companies to fully operate (Almuzaiqer, 2018; Ayamga \& Bagina, 2019; Donnell, 2019; Noble, 2019; Turtle \& Wang, 2017).

A study on the timeliness of report (Oussii \& Boulila Taktak, 2018; Sutopo et al., 2017), stated that the accounting information system has a timely effect on the financial statements. However, Du and $\mathrm{Wu}$ (2018); Johnston and Zhang (2018); Zaitul and Ilona (2019) concluded that it does not affect the timeliness of financial reports. Furthermore, Grace (2009); Luo (2017) reported that internal control had a positive effect on the timeliness of the submission of financial statements. This was in line with the report by Lubis (2016) on the cash receipt, cash expenditure, vendor, procurement, and staffing system to the timeliness of financial statement. The findings by Aula and Budisusetyo (2018); Susandya (2018) concluded that teamwork and internal control did not affect the accuracy of the financial statements submitted.

The research problem showed that the accounting information system, as well as teamwork and internal control, draw inconsistent conclusions about the timeliness of financial statements. As a benchmark for cooperative business progress, the management can present financial reports to meetings of members and other entities (Esho, 2001; Jovanović et al., 2017). However, the timeliness of the reports is closely related to the reliability of the system (Donnell, 2019) and the existence of teamwork (Black et al., 2018; Jin et al., 2019), as well as effective supervision by the supervisory board (Ayamga \& Bagina, 2019; Susanti, 2018). Therefore, this study examines the accounting information system, teamwork, and internal control that affect the timeliness of financial statement submission. This information is considered as a good signal for cooperatives since the report satisfied the principles of accountability and transparency. 
Mardi MARDI, Petrolis Nusa PERDANA, Suparno SUPARNO, Imam Aris MUNANDAR /

\section{Literature Review}

The compliance theory explains the role of indicators at the level of individual morality and should comply with all commonly-used rules and procedures (Festinger \& Carlsmith, 1959; Moody et al., 2018). However, Doherty and Tajuddin (2018) mentioning this theory emphasizes the role of socialization in an individual's compliance behavior.

Individuals tend to follow rules they deem appropriate and which correspond to their culture and internal norms (Festinger \& Carlsmith, 1959). The role of the normative commitment is assumed to conform to the rules of individual morality since they are considered as liabilities. Also, recognized normative obligations other than the established rules are accepted. This is because the party has the right to accept everything concerning the rules (Cuevas \& Fischer, 2006; Sohrabi Safa et al., 2016; Xue et al., 2011). The attitude of following the rules is interpreted in this case as being obedient and submissive (Doherty \& Tajuddin, 2018; Xue et al., 2011). Furthermore, compliance theory encourages individuals to obey and comply with regulations. This is no different from business organizations, which, for example, should immediately submit financial statements. Apart from being an obligation, compliance expects the company to submit financial statements as these reports are required by users (Doherty \& Tajuddin, 2018; Ifinedo, 2014; Sohrabi Safa et al., 2016).

Alali and Cao (2010); Reimsbach et al. (2018) affirmed that the quality of accounting information is relevant and reliable. The superiority of information that influences decisions is relevant to the main quality of reports (Alali \& Cao, 2010; Christensen et al., 2016). The appropriate form is its right-time function since annual financial statements are prepared to match the characteristics (Johnston \& Zhang, 2018). Besides reliability is an important characteristic in accounting information systems (Abu-Eker et al., 2019). Therefore, information is said to be reliable, when verified based on different hypotheses.

According to Almuzaiqer (2018); Susandya (2018), clear relevance is strongly related to timeliness. Accounting information is only relevant when presented immediately. Contrary to this, it becomes irrelevant, and cannot provide feedback as well as predictive value for users. This permanently removes the value of benefits for decisionmakers at the management level (Aula \& Budisusetyo, 2018; Trisanti, 2017; Zaitul \& Ilona, 2019).

Therefore, the method of measuring transparency and accountability in the delivery of financial statements requires the timeliness of information by users and should be available when needed. (Christensen et al., 2016; Johnston \& Zhang, 2018). Timeliness or late delivery will have different effects on the decisions taken (Aula \& Budisusetyo, 2018; Zaitul \& Ilona, 2019). Immediate decision making conveys useful information to users (Chiu et al., 2019; Doherty \& Tajuddin, 2018; Ifinedo, 2014).

The accounting information system is an integrated work that produces business transaction data through processing and presentation to generate useful report for users (Cleary, 2017; Hall, 2011; Romney \& Steinbart, 2014). It is related to the timeliness of report presentation because the information generated by AIS is a tool for managers. For company management and leadership, it is considered necessary to prepare a good financial statement presentation of the distribution and placement of activities performed together with the receipt of information as a form of financial data (Donnell, 2019; Kocsis, 2019; Nicolaou, 2000). The accounting periods can help management decisions on the assumption that financial statements are concluded on time (Chiu et al., 2019; Johnston \& Zhang, 2018).

The knowledge of managers about accounting information systems develops from the ability and expertise to understand its application through education, training, and experience (Kythreotis \& Constantinou, 2016; Oussii \& Boulila Taktak, 2018; Trisanti, 2017). An AIS operator will possess sufficient experience on the assumption that adequate educational criteria with the support of accounting information system training are provided (Donnell, 2019; Koo, 2018; Romney \& Steinbart, 2014). Edmonds et al. (2017); Johnston and Zhang (2018) explained that this system needs to be supported by appropriate facilities and equipment capable of performing the most important tasks according to a schedule. From this explanation, the hypothesis used is as follows:

H1: Accounting information systems affect the timeliness of financial statement submission.

Teamwork is a group where individuals show highperformance achievements (Costa et al., 2014; Jin et al., 2019), and another opinion defined it as a collection of more than one person pursuing a goal through the implementation of a collaborative strategy (Castner, 2012; Liaw et al., 2019). It is needed by the management in cooperative activities, and it allows timely completion of work. The existence of Teamwork in an entity reduces the overlapping of tasks or avoid the occurrence of work performed by one person. There is no explanation for the division of tasks and authority (Jin et al., 2019; Romney \& Steinbart, 2014; Solansky et al., 2017; Yoon \& Kayes, 2016). However, when the team leader does not show this form of cooperation, the management performance is considered not good (Cha, 2015; Jin et al., 2019).

On the contrary, when there is cooperation in a team, this condition can create a pleasant working and cooperating 
atmosphere for the existence of maximum achievements according to available data and information (Castner, 2012; Liaw et al., 2019). (Black et al., 2018; Jin et al., 2019) reported that teamwork is a reflection of the work coordination process, which helps to optimally achieve the goal. Furthermore, it can improve communication in every part of the entity (Solansky et al., 2017). Typically, teamwork is made up of people with different specialist knowledge. They work together to achieve company goals following the organization's vision and mission (Cha, 2015; Yoon \& Kayes, 2016). Almuzaiqer (2018); Costa et al. (2014) explain that teamwork can affect the timeliness of financial statements because its preparation and submission can be completed on time. Therefore, the financial statements still have the moment in time used as a decision-making tool (Solansky et al., 2017). According to this explanation, the hypothesis used in this investigation is:

\section{H2: Teamwork affects the timeliness of financial statement submission.}

Internal control (Ayamga \& Bagina, 2019; Hall, 2011; Septariani, 2018) is a protective system against various attacks on company assets. Also, Lu et al. (2019); Xiao (2019) gave a similar definition system. In internal control activities (Bentley-Goode et al., 2017; Jovanović et al., 2017; Noble, 2019) discovered that the interests of management are implementing measures to secure assets of the company as well as ensuring the reliability and accuracy of information necessary for external or internal users. Internal control aims to promote the operational efficiency of the entity and encourage compliance with management guidelines by company actors (Romney \& Steinbart, 2014; Sjarief \& Weli, 2016).

Furthermore, it has a close relationship with the timeliness of financial statement submission (Ayamga \& Bagina, 2019; Habib et al., 2017). This is evident from its existence in the form of reliability and accuracy of the information required for users of financial statements (Ayamga \& Bagina, 2019; Jovanović et al., 2017; Koo, 2018). The hypothesis used is as follows:

H3: Internal control affects the timeliness of financial statement submission.

\section{Research Methods and Materials}

This study aims to obtain empirical evidence about the determinants of financial reporting timeliness in cooperatives (Sekaran \& Bougie, 2017). These factors include the reliability of accounting information systems, teamwork, and internal controls. The cooperatives were studied in the city of Tangerang, with the criteria of having issued financial reports every period of the current year, and already have a certificate or legal entity (Septariani, 2018; Wibisono \& Setyohadi, 2018). The samples consist of 60 cooperative institutions and were studied using a simple random sampling technique (Sekaran \& Bougie, 2016). Also, data were obtained through a questionnaire using a Likert scale that was sent to the cooperative management in the form of a link Google form. The hypotheses were tested (Campbell et al., 2018) and analyzed using multiple linear regression. Prior to this, class-assumption test such as autocorrelation and multicollinearity was performed:

The model as shown below: Time $=\beta+\beta 1$ AIS $+\beta 2$ TW

$$
+\beta 3 \mathrm{IC}+\mathrm{e}
$$

Time: The timeliness of financial reporting.

AIS: Accounting Information System

TW: Teamwork

IC: Internal Control

e: error.

\section{Results and Discussion}

Normality tests are performed by observing the probability plot and concluding that the study data is normal. The multicollinearity test showed that there is no multicollinearity between the variables. The results of autocorrelation tests using the Durbin Watson (DW) value concluded that there was no correlation in the regression model. Three hypotheses were tested in this study using multiple linear regression. Before testing the hypothesis, a regression model was tested with the results shown in the following table:

According to Table 1, the results of the F test were 12.866 with a significance of 0.000 (Campbell et al., 2018). Since the significance level is smaller than 0.05 and the value of $\mathrm{F}_{\text {account }} 12.866$ is greater than $\mathrm{F}_{\text {table }} 2.77$, the regression model can be used to predict timeliness. However, the accounting information system, teamwork, and internal control all influence the timeliness of filing financial statements at the same time. Based on the results of the coefficient of determination tests in Table 1, the adjusted squared R-value is 0.376 or $37.6 \%$ which means that the accounting information system, teamwork, and internal control influences the timeliness of financial statement submission is $37.6 \%$. The remaining $62.4 \%$ can be explained by other factors outside the model.

Based on Table 2. Partial Testing, the fit model as shown below:

$$
\text { Time }=2.975+0.143 \mathrm{AIS}+0.136 \mathrm{TW}+0.159 \mathrm{IC}+\varepsilon
$$


Mardi MARDI, Petrolis Nusa PERDANA, Suparno SUPARNO, Imam Aris MUNANDAR /

Table 1: Model Summary and Coefficients Research Data

\begin{tabular}{|c|c|c|c|c|c|c|c|}
\hline \multirow{2}{*}{\multicolumn{2}{|c|}{ Model }} & \multicolumn{4}{|c|}{ Variables } & \multirow{2}{*}{$F$} & \multirow{2}{*}{ R Square } \\
\hline & & \multirow{2}{*}{$\begin{array}{c}\text { (Constant) } \\
2,975\end{array}$} & \multirow{2}{*}{$\begin{array}{c}\text { AIS } \\
0,143\end{array}$} & \multirow{2}{*}{\begin{tabular}{|c|} 
TW \\
0,136
\end{tabular}} & \multirow{2}{*}{$\begin{array}{c}\text { IC } \\
0,159\end{array}$} & & \\
\hline Unstandardized & $B$ & & & & & \multirow{5}{*}{12,866} & \multirow{5}{*}{0,408} \\
\hline Coefficients & Std. Error & 3,581 & 0,057 & 0,064 & 0,064 & & \\
\hline $\begin{array}{l}\text { Standardized } \\
\text { Coefficients }\end{array}$ & Beta & & 0,328 & 0,220 & 0,328 & & \\
\hline \multicolumn{2}{|c|}{$\mathrm{t}$} & 0,831 & 2,491 & 2,121 & 2,498 & & \\
\hline \multicolumn{2}{|l|}{ Sig. } & 0,410 & 0,016 & 0,038 & 0,015 & & \\
\hline
\end{tabular}

Table 2: Partial Testing Research Data

\begin{tabular}{|l|l|c|c|c|c|}
\hline \multirow{2}{*}{ Model } & \multicolumn{4}{|c|}{ Variables } \\
\cline { 3 - 6 } & (Constant): Time & AIS & TW & IC \\
\hline $\begin{array}{l}\text { Unstandardized } \\
\text { Coefficients }\end{array}$ & B & 2,975 & 0,143 & 0,136 & 0,159 \\
\cline { 2 - 6 } & Std. Error & 3,581 & 0,057 & 0,064 & 0,064 \\
\hline $\begin{array}{l}\text { Standardized } \\
\text { Coefficients }\end{array}$ & Beta & & 0,328 & 0,220 & 0,328 \\
\hline $\mathrm{t}$ & & 2.491 & 2.121 & 2.498 \\
\hline Sig. & 0,831 & 0,016 & 0,038 & 0,015 \\
\hline
\end{tabular}

Hypothesis 1 test results conclude that the accounting information system has a significance of 0.016 less than 0.05 and $t$ account 2.491 is greater than $t$ table 2.003. In conclusion Hypothesis 1 was accepted and was stated that accounting information system has a positive and significant effect on the timeliness of delivering financial statements of cooperatives. Therefore, with the increasing use of accounting information systems, the delivery of financial statements is said to be more timely. This conclusion is in accordance with Cleary (2017); Edmonds et al. (2017); Susandya (2018) and it showed a positive and significant effect on the timeliness of financial statement submission. However, this result is slightly different from the conclusion of Borsellino et al. (2020); Kythreotis and Constantinou (2016); Zaitul and Ilona (2019), which states that the information system does not affect the timeliness of financial reporting on large companies.

An accounting information system is a tool used to collect, process, and analyzes data to be communicated to users of financial statements (Hall, 2011; Romney \& Steinbart, 2014). They can solve accounting problems since activities are performed in an integrated manner according to the established targets (Donnell, 2019; Johnston \& Zhang, 2018). Users directly record various transactions in an already connected system. This system specifically handles financial reports to obtain responsible and transparent accounting financial reports as well as being a reference for decision-making (Lubis, 2016; Oussii \& Boulila Taktak, 2018).

Hypothesis 2 test shows that teamwork has a significant effect of 0.038 less than 0.05 and $t$ account 2.121 is greater than $t$ table 2.003. Therefore, the hypothesis was accepted since teamwork has a positive and significant impact on the speed of diploma submission. The more timely the financial statements, the better the teamwork in managing the cooperative (Jin et al., 2019; Solansky et al., 2017).

Teamwork is the bringing together of more than one person to achieve a goal, and a collaboration strategy is established. Also, it is an important element in achieving the vision and mission of the company. Therefore, teamwork can determine the timeliness of degree submissions (Black et al., 2018; Costa et al., 2014).

Furthermore, teamwork requires solid individuals to achieve the goals set when the team is formed. The ability to control oneself is required to avoid selfishness and achieve goals. Every person is expected to be democratic on the assumption that teamwork can produce a collaborative financial report promptly. This supports the results by Ketut et al. (2020); Liaw et al. (2019); Yoon and Kayes, (2016) stated that the team organization had a positive effect on the timeliness of delivering financial statements. 
Hypothesis 3 testing shows that internal control has a significance of 0.015 less than 0.05 and $t$ account 2.498 is greater than t table 2.003. This concludes that hypothesis 3 was accepted, and internal control has a positive and significant influence on the timeliness of financial statement submission. The better the application of internal control in cooperative management, the more timely the delivery of financial statements (Jovanović et al., 2017). This was supported by Bentley-Goode et al. (2017); Noble (2019); Schenk et al. (2018), where they reported a positive effect of timeliness.

Internal control is an integrated system that is performed by management to maintain and monitor readiness activities. It is put in place to secure the investments and assets of the company. Therefore, all members of the entity are required to create a pleasant working atmosphere, uphold integrity, and ethical value (Hall, 2011; Romney \& Steinbart, 2014). Companies need to continuously monitor the effectiveness of internal controls, especially when environmental conditions are constantly changing.

Internal control has a close relationship with the timeliness of financial statement submission (Ayamga \& Bagina, 2019; Habib et al., 2017), which shows its existence in the form of certainty of the reliability and accuracy of information (Ayamga \& Bagina, 2019; Jovanović et al., 2017; Koo, 2018). Preventive internal control is conducted by complying with various applicable laws to reduce or minimize the risk of an entity's activities. Furthermore, it provides the right information for managers and the board of directors to make the right decisions and policies (Chiu et al., 2019; Raweh et al., 2019).

\section{Conclusions}

The results concluded that the Accounting Information System has a positive and significant effect on the timeliness of delivering financial statements. It shows the increasing use of AIS, the precision and timely delivery of financial statements as well as its usefulness to users. Teamwork and internal control have a positive and significant impact on timeliness. It has a positive and significant effect on the timeliness of delivering financial statements. This shows that better coordination of the team leads to appropriate submission of financial statements since it does not lose momentum for users. In addition, internal control has a positive and significant effect on timeliness. This shows that the more effective the internal control, the more timely the delivery of financial statements and the more information may be needed. For the financial situation of the cooperative to influence the timely delivery of annual reports, those submitted should be accountable and transparent. Further study is expected to examine the factors of cooperative governance and the ability of human resources to investigate the causes of delay in submitting cooperative annual reports.

\section{References}

Abu-Eker, E. F. M., Jaradat, M. M. F., \& Alrawashdeh, I. A. (2019). Characteristics of Accounting Information Systems in Commercial Establishments in Irbid City. International Journal of Accounting and Financial Reporting, 9(2), 77. https://doi. org/10.5296/ijafr.v9i2.14511

Aktaş, R. (2011). Timeliness of reporting and the quality of financial information. International Research Journal of Finance and Economics, 63, 71-77. https://www.scopus. com/inward/record.uri?partnerID $=\mathrm{HzOxMe} 3 \mathrm{~b} \& \mathrm{scp}=79952$ 918930\& origin=inward

AL-Sharairi, M., Al-Hosban, A., \& Thnaibat, H. (2018). The impact of the Risks of the Input of Accounting Information Systems on Managerial Control, Accounting Control and Internal Control in Commercial Banks in Jordan. International Journal of Business and Management, 13(2), 96-107. https:// doi.org/10.5539/ijbm.v13n2p96

Alali, F., \& Cao, L. (2010). International financial reporting standards - credible and reliable? An overview. Advances in Accounting. https://doi.org/10.1016/j.adiac.2010.02.001

Almuzaiqer, M. A. (2018). Timeliness of financial reporting and audit committee effectiveness: evidence from UAE. UNIMAS Review of Accounting and Finance, 1(1), 99-112. https://doi. org/10.33736/uraf.931.2018

Arif, D., Yucha, N., Setiawan, S., Oktarina, D., Martah, V., \& Muttaqiin, N. (2020). Applications of goods mutation control form in accounting information system: A case study in sumber indah perkasa manufacturing, Indonesia. Journal of Asian Finance, Economics and Business, 7(8), 419-424. https://doi. org/10.13106/jafeb.2020.vol7.no8.419

Asher, M. G. (2007). Reforming governance and regulation of urban cooperative banks in India. Journal of Financial Regulation and Compliance. https://doi.org/10.1108/13581 980710726769

Aula, F., \& Budisusetyo, S. (2018). The Effect of Non-Financial and Financial Factors on the Timeliness of the Submission of Company Annual Financial Statements. The Indonesian Accounting Review, 8(1), 81-95. https://doi.org/10.14414/tiar. v8i1.1531

Awosejo, O.J, Kekwaletswe, R, M, Pretorius, P and Zuva, T. (2013). The Effect of Accounting Information Systems in Accounting. International Journal of Advanced Computer Research, 1(2), 21-31.

Ayamga, B. N., \& Bagina, R. W. (2019). The Effect of Internal Control Systems on Financial Performance in the Kassena Nankana Municipality, Upper East Region. Asian Journal of Economics, Business and Accounting, 1-13. https://doi. org/10.9734/ajeba/2019/v10i130098

Bagnoli, M., \& Watts, S. G. (2000). The effect of relative performance evaluation on earnings management: A gametheoretic approach. Journal of Accounting and Public Policy, 19(4-5), 377-397. https://doi.org/10.1016/S02784254(00)00005-3 
Bentley-Goode, K. A., Newton, N. J., \& Thompson, A. M. (2017). Business strategy, internal control over financial reporting, and audit reporting quality. Auditing, 36(4), 49 69. https://doi. org/10.2308/ajpt-51693

Bhimani, A. (2014). Digitisation, Big Data and the transformation of accounting information. Accounting and Business Research, 44(4), 469-490. https://doi.org/10.1080/00014788 .2014 .910051

Black, J., Kim, K., Rhee, S., Wang, K., Sakchutchawan, S., Black, J., Kim, K., Rhee, S., Wang, K., \& Sakchutchawan, S. (2018). Self-efficacy and emotional intelligence Influencing team cohesion to enhance team performance. Team Performance Management, 25(4). https://doi.org/10.1108/TPM-01-20180005

Borsellino, V., Varia, F., Zinnanti, C., \& Schimmenti, E. (2020). The Sicilian cooperative system of wine production: The strategic choices and performance analyses of a case study. International Journal of Wine Business Research, 32(3), 391-421. https:// doi.org/10.1108/IJWBR-10-.2018-0062

Campbell, Z., Bray, A., Ritz, A., \& Groce, A. (2018). Differentially private ANOVA testing. Proceedings - 2018 1st International Conference on Data Intelligence and Security, ICDIS 2018. https://doi.org/10.1109/ICDIS.2018.00052

Castner, J. (2012). Validity and reliability of the brief teamstepps teamwork perceptions questionnaire. Journal of Nursing Measurement, 20(3), 186-198. https://doi.org/10.1891/10613749.20.3.186

Cha, J. (2015). Transformational Leadership and Inter-Team Collaboration: Exploring the Mediating Role of Teamwork Quality and Moderating Role of Team Size. Group and Organization Management, 40(6), 715-743. https://doi. org/10.1177/1059601114568244

Chiu, V., Liu, Q., Muehlmann, B., \& Baldwin, A. A. (2019). A bibliometric analysis of accounting information systems journals and their emerging technologies contributions. International Journal of Accounting Information Systems, 32, 24-43. https://doi.org/10.1016/j.accinf.2018.11.003

Christensen, H. B., Nikolaev, V. V., \& Wittenberg-Moerman, R. (2016). Accounting Information in Financial Contracting: The Incomplete Contract Theory Perspective. Journal of Accounting Research, 54(2), 397-435. https://doi.org/10.1111/1475679X.12108

Cleary, M. (2019). Analisis Laporan Keuangan Berdasarkan PSAK No. 27 Studi Kasus Pada Primkopkar Carathana Jita Vina Kubu Raya. Journal of Chemical Information and Modeling. https:// doi.org/10.1017/CBO9781107415324.004

Cleary, P. (2017). Introduction to Accounting Information Systems. The Routledge Companion to Accounting Information Systems, 3-12. https://doi.org/10.4324/9781315647210-1

Costa, P. L., Passos, A. M., \& Bakker, A. B. (2014). Team work engagement: A model of emergence. Journal of Occupational and Organizational Psychology, 87(2), 414-436. https://doi. org/10.1111/joop.12057
Cuevas, C. E., \& Fischer, K. P. (2006). Cooperative Financial Institutions Issues in Governance, Regulation, and Supervision. In: Finance (Vol. 82, Issue Issues in Governance, Regulation, and Supervision). https://doi.org/10.1596/978-0-8213-6684-4

Doherty, N. F., \& Tajuddin, S. T. (2018). Towards a user-centric theory of value-driven information security compliance. Information Technology and People, 31(2), 348-367. https:// doi.org/10.1108/ITP-08-2016-0194

Donnell, J. B. O. (2019). Are Accounting Information Systems Programs Evolving to Meet the Needs of the Accounting Profession? An Analysis of Accounting Information Systems Programs in 2005 and 2019. Journal of Applied Business and Economics, 21(8), 81-91. https://doi.org/10.33423/jabe. v21i8.2591

Du, H., \& Wu, K. (2018). XBRL Mandate and Timeliness of Financial Reporting: Do XBRL Filings Take Longer? Journal of Emerging Technologies in Accounting, 15(1), 57-75. https:// doi.org/10.2308/jeta-52094

Edmonds, C. T., Edmonds, J. E., Vermeer, B. Y., \& Vermeer, T. E. (2017). Does timeliness of financial information matter in the governmental sector? Journal of Accounting and Public Policy, 36(2), 163-176. https://doi.org/10.1016/j. jaccpubpol.2017.02.002

Esho, N. (2001). The determinants of cost efficiency in cooperative financial institutions: Australian evidence. Journal of Banking and Finance, 25(5), 941-964. https://doi.org/10.1016/S03784266(00)00104-7

Festinger, L., \& Carlsmith, J. M. (1959). Cognitive consequences of forced compliance. Journal of Abnormal and Social Psychology, 58(2), 203-210. https://doi.org/10.1037/h0041593

Ghasemi, M., Shafeiepour, V., Aslani, M., \& Barvayeh, E. (2011). The impact of information technology (it) on modern accounting systems. Procedia - Social and Behavioral Sciences, 28, 112-116. https://doi.org/10.1016/j.sbspro.2011.11.023

Gui, A., Fernando, Y., Wiwoho, A. S., Handoko, B. L., \& Haron, H. (2019). The Influence of Internal Control, Leadership Style, and Teamwork to Information System Project Success. KnE Social Sciences, 593-602. https://doi.org/10.18502/kss.v3i22.5077

Ha, V. D. (2020). Impact of organizational culture on the accounting information system and operational performance of small and medium sized enterprises in Ho Chi Minh City. Journal of Asian Finance, Economics and Business, 7(2), 301-308. https://doi.org/10.13106/jafeb.2020.vol7.no2.301

Habib, A., Hasan, M. M., \& Al-Hadi, A. (2017). Financial statement comparability and corporate cash holdings. Journal of Contemporary Accounting \& Economics, 13(3), 304-321. https://doi.org/10.1016/j.jcae.2017.10.001

Hall, J. A. (2011). Accounting Information Systems ( $7^{\text {th }}$ ed.). Boston, MA: South-Western Cengagae Learning.

Huang, H. W. (2017). The Timeliness of Financial Reporting and Fair Values: Evidence from U.S. Banks. Review of Pacific Basin Financial Markets and Policies, 20(1). https://doi.org/10.1142/ S0219091517500060 
Hwang, S., No, W. G., \& Kim, J. (2020). XBRL Mandate and Timeliness of Financial Reporting: The Effect of Internal Control Problems. Journal of Accounting, Auditing \& Finance, 24(4), 543-579. 148558. https://doi. org/10.1177/0148558x20929854

Ifinedo, P. (2014). Information systems security policy compliance: An empirical study of the effects of socialisation, influence, and cognition. Information and Management, 51(1). https://doi. org/10.1016/j.im.2013.10.001

Ikatan Akuntansi Indonesia. (2016). Conceptual Framework for Financial Reporting. Dewan Standar Akuntansi Keuangan. https://doi.org/10.4337/9781845429997

Jin, T. F. (2003). Analysis of the factors that influence the use of information technology and the effect of the use of information technology on the performance of public accountants. Jurnal Bisnis Dan Akuntansi, 5(1), 1-26.

Jin, C. X., Li, F. C., Zhang, K., Xu, L. Da, \& Chen, Y. (2019). A cooperative effect-based decision support model for team formation. Enterprise Information Systems, 14(1), 110-132. https://doi.org/10.1080/17517575.2019.1678071

Johnston, J. A., \& Zhang, J. H. (2018). Information Technology Investment and the Timeliness of Financial Reports. Journal of Emerging Technologies in Accounting, 15(1), 77-101. https:// doi.org/10.2308/jeta-52066

Jovanović, T., Arnold, C., \& Voigt, K. I. (2017). Cooperative banks in need of transition: The influence of Basel III on the business model of German cooperative credit institutions. Journal of Co-Operative Organization and Management, 5(1), 39-47. https://doi.org/10.1016/j.jcom.2017.03.003

Kane, S. N., Mishra, A., \& Dutta, A. K. (2016). Preface: International Conference on Recent Trends in Physics (ICRTP 2016). Journal of Physics: Conference Series, 755(1). https:// doi.org/10.1088/1742-6596/755/1/011001

Ketut, I. G., Ulupui, A., Murdayanti, Y., Cita, A., \& Purwohedi, U. (2020). Green accounting, material flow cost accounting and environmental performance. Accounting, 6, 743-752. https:// doi.org/10.5267/j.ac.2020.6.009

Kocsis, D. (2019). A conceptual foundation of design and implementation research in accounting information systems. International Journal of Accounting Information Systems, 34, 100420. https://doi.org/10.1016/j.accinf.2019.06.003

Koo, C. O. (2018). A Study on the Financial Reporting of Cooperatives: Focusing on Social Cooperatives. Cooperative Management Review, 49, 29-53. https://doi.org/10.35443/ cmr.2018.49..002

Kythreotis, A. (2016). The interrelation among accounting quality, timeliness and relevance. Global Business and Economics Review, 18(5), 587-603. https://doi.org/10.1504/ GBER.2016.078677

Liaw, S. Y., Wu, L. T., Wong, L. F., Soh, S. L. H., Chow, Y. L., Ringsted, C., Lau, T. C., \& Lim, W. S. (2019). Getting Everyone on the Same Page: Interprofessional Team Training to Develop Shared Mental Models on Interprofessional Rounds. Journal of General Internal Medicine, 34(12), 2912-2917. https://doi. org/10.1007/s11606-019-05320-z

Liyundira, F. S., Yatminiwati, M., M, T., Irwanto, J., \& Fauziah, A. (2019). The Ability of Go-Public Companies in Financial Statements Timeliness. Journal of Advanced Research in Dynamical and Control Systems, 11(12), 9-16. https://doi. org/10.5373/jardcs/v11i12/20193206

Lu, Y., Zhan, H., \& Xiao, S. (2019). Internal Control, Financial Governance and Corporate Strategic Objectives Achievement. Accounting and Finance Research, 8(3), 157. https://doi. org/10.5430/afr.v8n3p157

Lubis, A. F. (2016). The role of Enterprise Resource Plan (ERP) configuration to the timeliness of the financial statement presentation. International Journal of Applied Business and Economic Research, 14(11), 7591-7608. https://www. scopus.com/inward/record.uri?partnerID $=\mathrm{HzOxMe} 3 \mathrm{~b} \& \mathrm{scp}=$ 85006250835\&origin=inward

Luo, M. (2017). Enterprise Internal Control and Accounting Information Quality. Journal of Financial Risk Management, 6(1), 16-26. https://doi.org/10.4236/jfrm.2017.61002

Mathuva, D. (2019). Corporate governance and the timeliness of audited financial statements: The case of Kenyan listed firms. Journal of Accounting in Emerging Economies, 9(4), 473-501. https://doi.org/10.1108/JAEE-05-2018-0053

Moffitt, K. C., \& Vasarhelyi, M. A. (2013). AIS in an age of big data. Journal of Information Systems, 27(2), 1-19. https://doi. org/10.2308/isys-10372

Moody, G. D., Siponen, M., \& Pahnila, S. (2018). Toward a unified model of information security policy compliance. MIS Quarterly: Management Information Systems, 42(1), 285-311. https://doi.org/10.25300/MISQ/2018/13853

Napitupulu, I. H. (2020). Internal Control, Manager's Competency, Management Accounting Information Systems and Good Corporate Governance: Evidence from Rural Banks in Indonesia. Global Business Review, 2147483647. https://doi. org/10.1177/0972150920919845

Nashihin, M., \& Harahap, L. (2014). The Analyis of the Efficiency of BPR-S: Production Function Approach Vs Financial Ratios Approach. Procedia-Social and Behavioral Sciences, 115(Iicies 2013), 188-197. https://doi.org/10.1016/j.sbspro.2014.02.427

Nicolaou, A. I. (2000). A contingency model of perceived effectiveness in accounting information systems: Organizational coordination and control effects. International Journal of Accounting Information Systems, 1(2), 91-105. https://doi. org/10.1016/S1467-0895(00)00006-3

Noble, M. R. (2019). Fraud diamond analysis in detecting financial statement fraud. The Indonesian Accounting Review, 9(2), 121-132. https://doi.org/10.14414/tiar.v9i2.1632

Oussii, A. A., \& Boulila Taktak, N. (2018). Audit committee effectiveness and financial reporting timeliness: The case of Tunisian listed companies. African Journal of Economic and Management Studies, 9(1), 34-55. https://doi.org/10.1108/ AJEMS-11-2016-0163 
Mardi MARDI, Petrolis Nusa PERDANA, Suparno SUPARNO, Imam Aris MUNANDAR /

Journal of Asian Finance, Economics and Business Vol 7 No 12 (2020) 809-818

Rapisarda, B. A. (2002). The Impact of Emotional Intelligence on Work Team Cohesiveness and Performance. The International Journal of Organizational Analysis, 10(4), 363-379.

Raweh, N. A. M., Kamardin, H., \& Malek, M. M. (2019). Audit Partner Quality and Audit Report Timeliness in Oman: A Conceptual Framework. International Journal of Accounting and Financial Reporting, 9(1), 450. https://doi.org/10.5296/ ijafr.v9i1.14478

Reimsbach, D., Hahn, R., \& Gürtürk, A. (2018). Integrated Reporting and Assurance of Sustainability Information: An Experimental Study on Professional Investors' Information Processing. European Accounting Review, 27(3). https://doi.or $\mathrm{g} / 10.1080 / 09638180.2016 .1273787$

Rikhardsson, P., \& Yigitbasioglu, O. (2018). Business intelligence $\&$ analytics in management accounting research: Status and future focus. International Journal of Accounting Information Systems, 29(April), 37-58. https://doi.org/10.1016/j.accinf. 2018.03.001

Romney, M. B., \& Steinbart, P. J. (2014). Accounting information systems. Upper Saddle River, NJ: Prentice Hall. https://doi. org/10.4324/9781315629520-20

Schenk, K., Gülbitti, B., \& Lunze, J. (2018a). Cooperative FaultTolerant Control of Networked Control Systems. IFACPapersOnLine, 51(24), 570-577. https://doi.org/10.1016/j. ifacol.2018.09.633

Sekaran, U., \& Bougie, R. (2016). Research methods for business: A skill building approach. Chichester, UK: John Wiley \& Sons, Incorporated.

Sekaran, U., \& Bougie, R. (2017). Research Methods for Business. Jakarta, Indonesia: Salemba Empat.

Septariani, J. (2018). Implementation of Cooperative Financial Accounting Standards Based on Sak-Etap in Village Unit Cooperatives. Jemasi: Jurnal Ekonomi Manajemen Dan Akuntansi. https://doi.org/10.35449/jemasi.v14i1.23

Sjarief, J., \& Weli, W. (2016). The internal control disclosure, the executive compensation, and the timeliness of financial reporting. International Journal of Applied Business and Economic Research, 14(2), 991-1002.

Sohrabi Safa, N., Von Solms, R., \& Furnell, S. (2016). Information security policy compliance model in organizations. Computers and Security, 56, 70-82. https://doi.org/10.1016/j. cose.2015.10.006

Solansky, S., Mciver, D., Solansky, S., \& Mciver, D. (2017). Team characteristics and leadership training participation participation. https://doi.org/10.1108/TPM-12-2016-0055

Sumaryati, A., Novitasari, E. P., \& Machmuddah, Z. (2020). Accounting Information System, Internal Control System, Human Resource Competency and Quality of Local Government Financial Statements in Indonesia. Journal of Asian Finance, Economics and Business, 7(10), 795-802. https://doi.org/10.13106/jafeb.2020.vol7.n10.795

Suparno, Wibowo, A., Mukhtar, S., Narmaditya, B. S., \& Sinta, H. D. (2019). The determinant factors of development batik cluster business: Lesson from Pekalongan, Indonesia. Journal of Asian Finance, Economics and Business, 6(4), 227-233. https://doi. org/10.13106/jafeb.2019.vol6.no4.227

Susandya, A. A. P. G. B. A. (2018). The Effect of Cooperative's Characteristic on Financial Reporting Timeliness. Sriwijaya International Journal of Dynamic Economics and Business, 2(4), 269-292. https://doi.org/10.29259/sijdeb.v2i4.269-292

Susanti, D. (2018). The Analysis of Traangle Fraud Factors to Fraudulent Financial Statement. Indonesian Journal of Business, Accounting and Management, 1(1). https://doi. org/10.36406/ijbam.v1i1.219

Sutopo, B., Sutaryo, \& Christian, Y. (2017). Empirical study of the determinants on audit reporting timeliness: Evidence from Indonesia. International Journal of Trade and Global Markets, 10(4), 303-313. https://doi.org/10.1504/IJTGM.2017.090272

Tanjung, Y. F. (2017). Implementation of Statement of Financial Accounting Standards (PSAK) No. 27 Concerning Cooperative Accounting in Nusa Tiga Employee Cooperative Office Unit of the Board of Directors of PT. Perkebunan Nusantara III Medan. ABA Journal. https://doi.org/10.1002/ejsp.2570

Trisanti, T. (2017). Do the financial report qualitities have effect on timeliness of financial reporting? The case of indonesian listed firms. Advanced Science Letters, 23(9), 9001-9004. https://doi. org/10.1166/asl.2017.10011

Turtle, H. J., \& Wang, K. (2017). The Value in Fundamental Accounting Information. Journal of Financial Research, 40(1), 113-140. https://doi.org/10.1111/jfir.12119

Vysotskaya, A. B. (2018). Role of Matrix Accounting and Accounting Information Systems in Reliability Reporting of Business Entities Financial Activity. Accounting. Analysis. Auditing, 5(4), 94-99. https://doi.org/10.26794/2408-93032018-5-4-94-99

Wibisono, Y. P., \& Setyohadi, D. B. (2018). Accounting information system for nonprofit organization based on PSAK 45 standards. Proceedings - 2017 2nd International Conferences on Information Technology, Information Systems and Electrical Engineering, ICITISEE 2017. https://doi.org/10.1109/ ICITISEE.2017.8285482

Wisna, N. (2015). Organizational culture and its impact on the quality of accounting information systems. Journal of Theoretical and Applied Information Technology, 82(2), 266-272.

Xiao, F. (2019). Design and Analysis of a Strengthen Internal Control Scheme for Smart Trust Financial Service. IEEE Access, 7, 163202-163218. https://doi.org/10.1109/ ACCESS.2019.2945056

Xue, Y., Liang, H., \& Wu, L. (2011). Punishment, justice, and compliance in mandatory IT settings. Information Systems Research, 22(2), 400-414. https://doi.org/10.1287/ isre. 1090.0266

Yoon, J., \& Kayes, D. C. (2016). Employees' self-efficacy and perception of individual learning in teams: The crosslevel moderating role of team-learning behavior. Journal 
of Organizational Behavior, 37(7), 1044-1060. https://doi. org/10.1002/job.2092

Young, A. (2017). Do analysts affect bad news timeliness? Accounting and Business Research, 48(2), 171-189. https:// doi.org/10.1080/00014788.2017.1360174
Zaitul, \& Ilona, D. (2019). Gender in audit committee and financial reporting timeliness: The case of unique continental European model. International Journal of Recent Technology and Engineering, 8(Special Issue 9), 864-871. https://doi. org/10.35940/ijrte.B1178.0982S919 